WellBeing International

WBI Studies Repository

1999

\title{
Animals \& Society Courses: A Growing Trend in Post-Secondary Education
}

Jonathan Balcombe

The Humane Society of the United States

Follow this and additional works at: https://www.wellbeingintlstudiesrepository.org/acwp_he

Part of the Curriculum and Instruction Commons, Humane Education Commons, and the Social and Philosophical Foundations of Education Commons

\section{Recommended Citation}

Balcombe, J. (1999). Animals \& Society courses: A growing trend in post-secondary education. Society \& Animals, 7(3), 229-240.

This material is brought to you for free and open access by WellBeing International. It has been accepted for inclusion by an authorized administrator of the WBI Studies Repository. For more information, please contact wbisr-info@wellbeingintl.org.

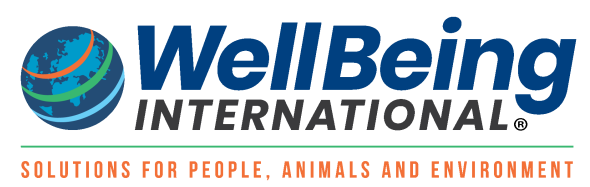




\title{
Animals \& Society Courses:
}

\section{A Growing Trend in Post-Secondary Education}

\author{
J onathan Balcombe
}

\section{Recommended Citation:}

Balcombe, J. (1999). Animals \& Society courses: A growing trend in post-secondary education. Society \& Animals, 7(3), 229-240.

\begin{abstract}
A survey of college courses addressing nonhuman animal ethics and welfare issues indicates that the presence of such courses has increased greatly since a prior survey was done in 1983. This paper provides titles and affiliations of 67 of 89 courses from the current Survey. These courses represent 15 academic fields, and a majority are entirely devoted to animal issues. The fields of animal science and philosophy are proportionally well represented compared with biology and wildlife-related fields. An estimated 5000 or more North American students are now receiving instruction in these issues each year. While the availability of courses in animal issues is still sporadic, it is unprecedentedly high and seen as an important component of changing social values toward nonhuman animals.
\end{abstract}

\section{NTRODUCTI ON}

Societal concern for nonhuman animals-be it for their welfare or for their rights-has increased markedly over the past half-century. The 1959 publication of Russell and Burch's The Principles of Humane Experimental Technique is rightfully acknowledged as providing the framework and much of the impetus for the development and application of humane alternatives to the use of animals in research, testing, and education. Similarly, the 1975 publication of Singer's Animal Liberation is widely credited with launching the modern animal rights movement. In the United States, passage of the Animal Welfare Act in 1966-and several subsequent amendments to it-was another landmark event in this heightened awareness and concern for animals.

An important manifestation of this growth in society's concern for animals is the increased presence of Animals \& Society ${ }^{1}$ courses (A\&SC) in university and college (hereafter, college) curricula which address ethical issues relating to human interactions with other animals. The presence of any issue in the academic sphere is a significant measure of the importance society places on it. The movement to free animals from human exploitation clearly has a viable and rigorous academic life, and the ideas discussed in the classrooms and hallways of academia are bound to make their way into the consciousness of the general public.

In this paper I present information gathered from a recent survey of A\&SCs offered at colleges in the United States and Canada and findings from a brief questionnaire sent to the course instructors. 
Hopefully, information gleaned from this study will help to foster continued expansion in this area of teaching as well as provide the reader with a status report on the teaching of $A \& S$ issues.

\section{PRI OR SURVEYS OF ANI MALS \& SOCI ETY COURSES}

Philosopher Bernard Rollin reports that virtually no courses addressed these issues before 1978, when he first taught an A\&SC to veterinary students at Colorado State University (personal communication, March 16, 1999). An explosion of new courses, unmatched since, occurred in the following five years. In 1979, Barbara Orlans, then president of the Scientists' Center for Animal Welfare, compiled and printed in SCAW Newsletter a list of nine courses in three academic disciplines: biology, philosophy, and veterinary medicine (SCAW, 1979). Eight of these courses placed a strong emphasis on the human/animal interrelationship; seven of them explicitly addressed "animal rights" and/or the "moral status of animals" (SCAW, 1979). In 1980, and again in 1983, SCAW updated its course listing and reported, respectively, 15 courses in five disciplines: biology, philosophy, veterinary medicine, religion, and environmental studies (SCAW, 1980); and 21 in 8 disciplines: philosophy, religion, biology; veterinary medicine, humanities, psychology, law, and public health (SCAW, 1983). To our knowledge, no survey of A\&SC has been conducted since 1983.

\section{METHODS}

The data on A\&SCs presented here were gathered from a combination of known contacts, word-ofmouth, announcements by academic associations such as the Association for Practical and Professional Ethics, the Journal of Agricultural and Environmental Ethics, and by Internet searches. The efficiency of electronic mailing facilitated the gathering of information for this project. Nevertheless, this list is not comprehensive; and some extant courses-especially introductory ethics courses that include a section on A\&S issues-are not accounted for in this study Hopefully, this paper will prompt instructors or students of such courses to notify me of their existence.

As in the earlier lists published by SCAW, many of the courses included in this survey and list are not entirely, or even primarily, devoted to animal issues. I included courses that devoted at least one course section to A\&S issues. In most cases, this amounts to at least a few lectures and/or class discussion sessions on A\&S topics.

The survey we sent (most via e-mail) to course instructors was designed to get further information on the history and the enrollment figures of the courses, as well as their availability to students. The survey posed the following questions:

1. How long have you been teaching your course/s?

2. Is your course a requirement for any majors? If so, which one/s?

3. What is your course's enrollment capacity?

4. How many students take the course in an average year?

5. May a student not already enrolled in the institution take your course?

6. List the four or five most important texts you feel your students should read.

7. Would you be interested in being involved in the establishment of a virtual (Internet/telephone) university that would provide instruction on animal issues and, eventually, degrees?

8. Please add any further comments you wish to make. 


\section{RESULTS}

Currently, we know of 89 A\&SCs, with fairly widespread geographical representation in both the United States and Canada. Twenty-five states and the District of Columbia offer at least one course. The Canadian provinces of Ontario and British Columbia also offer at least one course. In addition, three multi-course programs focus on A\&S issues: (a) the Masters Degree Program in Animals and Public Policy, Tufts University School of Veterinary Medicine; (b) the Animal Welfare Program, University of British Columbia's Department of Agricultural Sciences; and (c) the Animal Rights Law program, Rutgers Animal Rights Law Clinic, Rutgers University School of Law. The Rutgers Clinic, however, has recently been discontinued.

Table 1 presents information on those courses $(n=67)$ for which we received responses to our survey. Because the availability and content of college courses change frequently, a published list of all courses would quickly go out-of-date. For a regularly updated, comprehensive list of A\&SCs and their instructors, we encourage readers to visit the following page on The Humane Society of the United States (HS US) website: <http://www.hsus.org/programs/research/courses.htmt>. We received responses to our survey from 55 of the 75 (73\%) instructors to whom we sent it. Because some instructors teach more than one A\&SC, the total number of courses for which we received survey information was 67 . The remainder of the results presented below refer to these courses only.

Of the courses for which we received survey responses, $41(62 \%)$ are devoted entirely to A\&S issues; the remainder devote some significant portion of the course to them (see above). Of the 15 academic fields represented, the best represented are philosophy (19 courses; $28 \%$ of the total), animal science (13 courses; 19\%), veterinary medicine (10 courses; 15\%), and law (9 courses; 13\%). While engaged in this study, we learned that, beginning in the summer of 1999, Harvard Law School would offer its first course in animal law.

The average number of years that A\&SCs for which we received survey responses have been taught is $7.14( \pm 5.11)$ years. Of the 52 courses for which we have sufficient data, $33(54 \%)$ are enrolled to capacity, $21(36 \%)$ are enrolled below capacity, and the remaining $6(10 \%)$ have no enrolled limit. Of the 21 courses below capacity, $12(57 \%)$ had been taught for three or fewer years. Though we did not solicit information on enrollment trends, three instructors voluntarily reported that enrollment numbers were steadily increasing; none reported a decline.

Twenty-three of 67 courses (35\%) for which we have data are required for at least one major; the remaining 44 courses (65\%) are electives. Thirty-three courses (48\%) may be taken for credit by someone not enrolled at the university, and 21 (31\%) may not. Four courses are available for audit. Access for non-registered students to nine courses is not known.

The readings used by course instructors collectively comprise an impressive list of over 50 volumes, plus numerous journal articles. It would take too much space to list them all in this article, but HSUS intends to compile reading lists based on the recommendations of A\&SC instructors. Authors most often mentioned in our survey responses were, in order of frequency, Singer (1975), Regan (1983), Regan and Singer (1976), Rollin (1981, 1989) Adams (1990), Orlans (1993), Rachels (1990), Tannenbaum (1995), Dawkins (1980, 1993), and Appleby and Hughes (1997). Notwithstanding the variety of available materials, certain respondents identified two needed texts: an anthology of readings, pro and con, in animal ethics covering (a) moral status, animal minds, vegetarianism, research, hunting, and companion animals: and (b) a case book of animal law. Four lawyers/instructors have written an 800-page animal law casebook for use in courses on animal law. Publication is expected by the year 2000.

The notion of a virtual university for instruction in A\&S issues met with mixed interest. About $80 \%$ of the respondents were either interested or possibly interested, and two were positively enthusiastic. 
Many of the instructors wanted to know more about such a project before they would state their endorsement of it. Two respondents mentioned that they had been considering the establishment of distance learning programs in $A \& S$. Another thought that training of instructors was the greatest need, as personal experience indicated that departments tend to select unqualified faculty to teach introductory A\&SCS.

\section{DISCUSSION}

This study allows a comparison between the current situation and the status of A\&SCs when they were first offered-20 years ago. The explosive rise in A\&SCs that occurred in the early 1980s has slowed, but the total number of available courses continues to rise steadily. The academic scope of these courses has also risen, with a doubling in the number of disciplines with A\&SCs since SCAW's 1983 survey. Of the 31 course instructors listed by SCAW in 1983, we know of only three who are instructing $A \& S C S$ today, suggesting both high turnover and high influx of instructors in A\&SCs.

That most of the courses are enrolled to capacity even though most are not core degree requirements indicates high student interest in A\&S issues. Conversely, courses enrolled below capacity need not imply a deficit of student interest but instead could indicate that more seats are available than students to fill them. At any rate, this measure is probably not very useful in gauging student interest. A class, for example, with 40 students in a room that the university determines could seat 50 would be under-enrolled. One with only 15 students in a seminar room would not.

Because the number of students enrolled varies greatly among different courses (see Table 1), extrapolating from numbers of courses to numbers of students taking them is not straightforward. However, survey data on course enrollment permit some assessment of this measure. From the survey responses alone (i.e., not including 22 courses for which we have no such data), the total number of college students who are receiving some significant form of schooling in A\&S issues is about 3,592 per year. If we extrapolate from the survey respondents to include those instructors who did not respond and also consider that a number of as yet unidentified A\&SCS probably remain, the number may well range from 4,000 to more than 5,000 students.

Comparing the number of $A \& S C S$ in a given discipline with the total number of programs in that discipline sheds light on the level of attention being given to animal ethics issues in these academic fields. For example, the field of animal science is relatively active in this area of instruction; twelve of 133 institutions (9\%) listed in Lovejoy's College Guide (Straughn \& Straughn, 1997) include ethical issues in animal treatment in their programs. By contrast, to our knowledge, none of the 145 degree listed programs in wildlife ("Wildlife and Fish Management." and "Conservation and Wildlife" combined) address these issues. Similarly, while we know that at least 19 of $800(2.4 \%)$ of listed philosophy degree programs address A\&S (Straughn \& Straughn, 1997), we know of only three of $1,382(0.2 \%)$ biology programs that do so. Of course, even for the programs that are more inclusive of $A \& S$ issues, these numbers are sobering reminders of how far academia is from routine inclusion of these issues in their disciplines.

Nevertheless, given that A\&SCs didn't exist just a few decades ago, their presence today is significant. Perhaps more significant is their making inroads into scientific fields that have historically tended to keep animal ethics issues at arm's length (i.e., animal science, biology, medicine, natural science, and psychology). Historically, consideration of moral and value issues concerning animals has been absent from the training of scientists, with the unfortunate result that scientists have tended to be naive and simplistic in their approaches to these matters (Rollin, 1989). The historical tradition has been that scientists must learn to objectify animals and to reject the natural tendency to feel ethical concern for them. A\&SCs can help to preclude this objectification by teaching budding scientists to examine their 
assumptions critically, to view the scientific method with healthy skepticism, and to not recoil from value issues (Rollin, 1989).

A\&SCs also help to legitimize moral concern for animals. Such is the current state of human cultural evolution that many people grow up not realizing that animals matter morally, or that the notion of animal rights, however radical-sounding to the uninitiated, has been championed by cogent, scholarly argument (Singer, 1975; Rollin, 1981; Regan, 1983; Rachels, 1990; Shapiro, 1998). The rising of animals beyond their current legal status as human property (Francione, 1995, 1996) is not likely to happen in the absence of academic debate. Until recently, the notion of granting personhood status to any nonhuman animal would have been viewed as misguided and ridiculous. Yet, less than a decade after The Great Ape Project (GAP) was formed and a book published arguing for such status (Cavalieri \& Singer, 1993), New Zealand has come close to taking this unprecedented step (Dyer, 1999). The evolving trends in A\&SC offerings and the progress of projects like GAP will be valuable indicators of the health and maturity of the social movement for animals into the new millennium.

\section{NOTES}

${ }^{1}$ I use the term "Animals \& Society" to embrace all issues concerning animal ethics, welfare, rights, etc. The term is not meant to apply only to topics related to human/animal relationships.

Table 1. Animals \& Society Courses Currently Taught in U.S. and Canadian Colleges and Universities

\section{LEGEND}

Yrs: $\quad$ Number of years instructor has taught A\&S course(s)

Alloc: Allocation of course to A\&S content ("part" means $<50 \%$ allocation)

Req: $\quad$ Required course

Cap: Enrollment capacity

Enr: Number of students enrolling in the course in an average year. (In cases of "no limit," capacity was treated as equal to enrollment.)

Acc: Access: student must be registered at the institution to take the course

\begin{tabular}{|c|c|c|c|c|c|c|c|c|}
\hline Academic Field & I nstitution & Course Title & Yrs & Alloc & Req & Cap & Enr & Acc \\
\hline Animal Science & $\begin{array}{l}\text { Colorado State } \\
\text { University }\end{array}$ & $\begin{array}{l}\text { Ethical Issues in Animal } \\
\text { Agriculture }\end{array}$ & 19 & Full & No & 40 & 40 & No \\
\hline Animal Science & $\begin{array}{l}\text { Colorado State } \\
\text { University }\end{array}$ & Agricultural Ethics & 2 & Part & No & 45 & 45 & No \\
\hline Animal Science & Cornell University & Ethics and Animal Science & 6 & Full & No & 20 & 20 & Yes \\
\hline Animal Science & $\begin{array}{l}\text { Kansas State } \\
\text { University }\end{array}$ & $\begin{array}{l}\text { Contemporary Issues in } \\
\text { Animal Science }\end{array}$ & 7 & Most & No & 24 & 24 & Yes \\
\hline Animal Science & $\begin{array}{l}\text { University of British } \\
\text { Columbia }\end{array}$ & $\begin{array}{l}\text { Animal Welfare and Ethics of } \\
\text { Animal Use }\end{array}$ & 2 & Full & No & 40 & 25 & Yes \\
\hline Animal Science & $\begin{array}{l}\text { University of British } \\
\text { Columbia }\end{array}$ & $\begin{array}{l}\text { Current Issues in Animal } \\
\text { Welfare }\end{array}$ & 1 & Full & Yes & 12 & 10 & Yes \\
\hline Animal Science & UC, Davis & Animal Welfare & 9 & Full & Yes & 40 & 40 & Audit \\
\hline Animal Science & UC, Davis & Ethics of Animal Use & 10 & Full & Yes & No limit & 80 & Audit \\
\hline Animal Science & University of Guelph & $\begin{array}{l}\text { Principles of Farm Animal Care } \\
\text { and Welfare }\end{array}$ & 10 & Full & Yes & No limit & 70 & No \\
\hline Animal Science & $\begin{array}{l}\text { University of Illinois, } \\
\text { Urbana-Champaign }\end{array}$ & $\begin{array}{l}\text { Human-Companion Animal } \\
\text { Interactions }\end{array}$ & 5 & Full & No & 25 & 25 & Yes \\
\hline
\end{tabular}

Note: only courses for which we received survey responses are included here; a more complete list of courses can be found at http://www.hsus.org/programs/research/courses. html 


\section{REFERENCES}

Adams, C. J. (1990). The sexual politics of meat. Cambridge: Polity/Blackwell.

Appleby, M. C. \& Hughes, B. O. (Eds.). (1997). Animal welfare. Oxfordshire: CAB International.

Dawkins, M. S. (1980). Animal suffering: The science of animal welfare London: Chapman and Hall.

Dawkins, M. S. (1993). Through our eyes only? The search for animal consciousness. New York: W. H. Freeman.

Cavalieri, P. \& Singer, P. (Eds.). (1993). The great ape project: Equality beyond humanity. New York: St. Martin's Press.

Dyer, G. (1999, April 5). The community of equals. The Washington Times, p. A15

Francione, G. L. (1995). Animals, property and the law. Philadelphia: Temple University Press,

Francione, G. L. (1996). Rain without thunder: The ideology of the animal rights movement. Philadelphia: Temple University Press.

Orlans, F. B. (1993). In the name of science: Issues in responsible animal experimentation. New York: Oxford University Press.

Rachels, J. (1990). Created from animals: The moral implications of Darwinism. New York: Oxford University Press.

Regan, T. (1983). The case for animal rights. Berkeley: University of California Press.

Regan, T. \& Singer, P. (Eds.). (1976). Animal rights and human obligations. New Jersey: Prentice-Hall.

Rollin B. E. (1981). Animal rights and human morality. Buffalo: Prometheus Books.

Rollin, B. E. (1989). The unheeded cry: Animal consciousness, animal pain, and science. United Kingdom: Oxford University Press.

Russell, W. M. S. \& Burch, R. L. (1959). The principals of humane experimental technique. London: Methuen.

SCAW (1979). Courses on ethics and animals. SCAW Newsletter 3, 4-5.

SCAW (1980). Courses on ethics and animals. SCAW Newsletter 2(4), 15.

SCAW, (1983). College courses on ethics and animals. SCAW Newsletter 5(2), 3-7.

Shapiro, K. (1998). Animal models of human psychology: Critique of science, ethics, and policy. Seattle: Hogrefe $\&$ Huber.

Singer, P. (1975). Animal liberation: A new ethics for our treatment of animals. New York: New York Review of Books.

Straughn, C. T. \&. Straughn, B. L. (1997). Lovejoy's college guide, 24th edition. New York: Macmillan.

Tannenbaum, J. (1995). Veterinary ethics: Animal welfare, client relations, competition and collegiality (2nd ed.) St. Louis: Mosby Year Book. 